\title{
Implementasi Naives Bayes-Certainty Factor untuk Diagnosa Penyakit Menular Ayam
}

\author{
Yudi Eko Windarto ${ }^{[1]}$, Marfuah ${ }^{[2]}$ \\ Departemen Teknik Komputer, Fakultas Teknik, Universitas Diponegoro ${ }^{[1]}$ \\ Jalan Prof Sudharto,SH, Tembalang, Kota Semarang, Jawa Tengah 50275 - Indonesia \\ Prodi Sistem Informasi, Fakultas Komputer, Universitas Universal ${ }^{[2]}$ \\ Kompleks Maha Vihara Duta Maitreya, Sungai Panas, Batam 29456, Kepulauan Riau - Indonesia \\ yudi@live.undip.ac.id ${ }^{[1]}$, marfuah916@gmail.com ${ }^{[2]}$
}

\begin{abstract}
One type of pet is Chicken (Gallus gallus domesticus). Chickens are the result of the domestication of red jungle fowl (Gallus gallus) which is most commonly kept throughout the world. These animals include animals that are easily maintained because they are good at adapting to various conditions of the place. Types of chickens include Broiler, Kedu, Nunukan, Pelung, Garut. Chicken disease can be caused by bacteria, parasites, and viruses. Sometimes the guards don't know that their pet chickens are sick. This can result in death due to delay in handling given. There are also owners who self-treat their chickens, without knowing clearly beforehand what diseases they are suffering from and what drugs are suitable for the disease. Other factors that influence the occurrence of this problem include the limited availability of veterinarians and are not always available at all times. Therefore, an alternative is needed that can provide convenience and ability like a veterinarian in diagnosing infectious diseases suffered by domestic chickens using the naüve bayes method - certainty based on android with 15 types of diseases including Avian influenza, Encephalomyelitis, Chlamydiosis, Pullorum, Fowl Typhoid, Chicken Pox, Chicken anemia syndrome, Helicopter Disease, Aspergillosis, Infectious Bursal Disease, Infectious Bronchitis, Diarrhea, Bacterial Pododermati, Pyotraumatic Dermatitis and Pyoderma. Analysis of test results is done by comparing the results of system diagnoses with the results of diagnoses performed by experts based on the input of the same symptoms from 50 test data, it is known that 45 system test data are declared to match the expert test data, the accuracy of the accuracy of diagnosis results of $90 \%$ is in good category.
\end{abstract}

Keywords-Chicken, disease, diagnose, Nä̈ve Bayes, Certainty Factor.

Abstrak- Salah satu jenis hewan peliharaan yaitu Ayam (Gallus gallus domesticus). Ayam merupakan hasil dari domestikasi ayam hutan merah (Gallus gallus) yang paling banyak dipelihara di seluruh dunia. Hewan ini termasuk hewan yang mudah dipelihara karena jago beradaptasi dengan berbagai kondisi tempat. Jenis ayam tersebut diantaranya Broiler, Kedu, Nunukan, Pelung, Garut. Penyakit ayam dapat disebabkan oleh bakteri, parasit, dan virus. Terkadang para penjaga tidak tahu bahwa ayam peliharaannya sakit. Hal ini dapat berakibat kematian yang disebabkan keterlambatan penanganan yang diberikan. Ada juga pemilik yang mengobati sendiri ayam mereka, tanpa mengetahui dengan jelas sebelumnya penyakit apa yang diderita dan obat apa yang cocok untuk penyakit tersebut. Adapun faktor lain yang mempengaruhi terjadinya permasalahan ini diantaranya ketersediaan dokter hewan yang terbatas dan tidak selalu tersedia setiap saat. Oleh sebab itu, suatu alternatif diperlukan yang dapat memberikan kemudahan dan kemampuan layaknya dokter hewan dalam mendiagnosis penyakit menular yang diderita oleh ayam peliharaan menggunakan metode naïve bayes - certainty factor berbasis android dengan 15 jenis penyakit diantaranya Avian influenza, Encephalomyelitis, Chlamydiosis, Pullorum, Fowl Typhoid, Cacar Unggas, Chicken anemia syndrome, Helicopter Disease, Aspergillosis, Infectious Bursal Disease, Infectious Bronchitis, Diare, Bacterial Pododermati, Pyotraumatic Dermatitis dan Pyoderma. Analisis hasil pengujian dilakukan dengan membandingkan hasil diagnosa sistem dengan hasil diagnosa yang dilakukan oleh pakar berdasarkan masukan gejala yang sama dari 50 data uji, di ketahui bahwa 45 data uji sistem dinyatakan cocok dengan data uji pakar, tingkat akurasi ketepatan hasil diagnosis sebesar $\mathbf{9 0 \%}$ berada dalam kategori baik.

Kata Kunci-Ayam, Penyakit Menular, Diagnosa, Nä̈ve Bayes, Certainty Factor.

\section{PENDAHULUAN}

Ayam merupakan salah satu hewan ternak atau peliharaan. Ayam termasuk salah satu hewan yang paling banyak dipelihara. Ayam jinak yang dipelihara manusia saat ini berasal dari ayam liar atau ayam hutan (Gallus gallus). Keturunan ayam yang telah menjadi jinak kemudian dikawinkan secara silang oleh manusia [1].

Ayam sebagai hewan peliharaan tidak luput dari interaksi dengan sesama ataupun manusia. Hal ini dapat menimbulkan dampak buruk bagi manusia terlepas dari berbagai macam manfaat yang dapat diperoleh. Pemilik hewan peliharaan harus mengetahui bagaimana cara merawat dan menjaga kesehatan hewan peliharaannya dengan baik dan benar, agar terhindar dari berbagai macam penyakit yang dapat menular [2][3]. Apabila ayam tidak dirawat dengan baik, maka akan berdampak buruk bagi kondisi kesehatannya dan dapat 
terserang penyakit menular sehingga dapat menyebabkan kematian, baik terhadap ayam yang menularkan maupun yang ditularkan [4].

Penyakit ayam sangat banyak dan beragam penyebabnya, serta mungkin saja para pemelihara ayam tidak tahu apa saja penyakitnya dan bagaimana cara penanganannya. Pemilik kadang mengobati sendiri ayamnya, tanpa mengetahui dengan jelas terlebih dahulu apa penyakit yang sedang dideritanya dan apa obat yang cocok untuk penyakit tersebut.

Penyebab dari penyakit ayam dapat disebabkan oleh bakteri, parasit, dan virus. Pemilik ayam kadang kurang memiliki pengetahuan untuk dapat memelihara ayam yang baik dan pencegahan penyakit yang dapat diderita ayam peliharaannya. Ayam yang terjangkiti penyakit menular akan dapat menularkan penyakitnya ke ayam lainnya dan beberapa penyakit sulit untuk diberantas [2][3]. Pemilik ayam membutuhkan bantuan seorang pakar untuk mengatasi masalah tersebut yaitu dokter hewan. Dikarenakan keberadaan dokter hewan yang terbatas dan tidak selalu ada setiap saat, maka diperlukan suatu alternatif yang dapat memberikan kemudahan dan memiliki kemampuan layaknya seorang dokter hewan dalam mendiagnosa penyakit menular yang diderita oleh ayam peliharaannya. 15 jenis penyakit menular ayam yang didapat kan dari 3 orang pakar diantaranya Avian influenza, Encephalomyelitis, Chlamydiosis, Pullorum, Fowl Typhoid, Cacar Unggas, Chicken anemia syndrome, Helicopter Disease, Aspergillosis, Infectious Bursal Disease, Infectious Bronchitis, Diare, Bacterial Pododermati, Pyotraumatic Dermatitis dan Pyoderma. Penyakit-penyakit menular ini diantaranya terjadi pada ayam berjenis Broiler, Kedu, Nunukan, Pelung, Garut.

Beberapa penelitian terkait diagnosa penyakit pada hewan peliharaan seperti aplikasi algoritma nä̈ve bayes untuk mendiagnosa penyakit sapi potong [5]. Menurut [6] naive bayes merupakan teknik probabilitas yang mampu menyelesaikan masalah ketidakpastian dengan konsep probabilitas hipotesis dan evidence [7]. Teknik probabilitas ini dapat digunakan dalam memprediksi suatu penyakit yang diderita.

Penelitian berikutnya mengenai sistem pakar diagnosis penyakit sapi dengan metode certainty factor berbasis Android [8]. Certainty Factor menyatakan kepercayaan dalam sebuah kejadian (fakta atau hipotesa) berdasar bukti atau penilaian pakar [9]. Certainty Factor memiliki tingkat keakuratan yang lebih tinggi dibandingkan dengan metode lainnya karena cara perhitungannya yang hanya dapat membandingkan tiap dua nilai saja [10].

Penelitian selanjutnya menggunakan metode nä̈ve bayes dengan certainty factor pada sistem pakar diagnosa penyakit saluran pencernaan ayam broiler untuk membantu para peternak [2]. Penelitian perbandingan metode nä̈ve bayes dengan certainty factor dilakukan dalam penelitian dengan objek tanaman melon membandingkan gejala-gejala penyakit yang dapat menyerang tanaman. Sistem aplikasi diagnosa berbasis web namun peneliti mengharapkan dapat dibuat dalam aplikasi android.

Berdasarkan beberapa landasan tersebut, maka penelitian ini mengkaji mengenai metode nä̈ve bayes : certainty factor untuk diagnosa penyakit menular pada hewan peliharaan ayam berbasis android dengan menggunakan 50 data uji.

\section{TINJAUAN PUSTAKA}

Adapaun beberapa penelitian terkait yang pernah dilakukan sebelumnya mengenai metode, objek yang digunakan dan metode lain yang dapat digunakan pada kasus serupa diantaranya. Menurut [4] Penelitian pertama mengenai aplikasi algoritma naive bayes untuk mendiagnosa penyakit anjing. Algoritma naive bayes digunakan untuk mengklasifikasi dan menentukan probabilitas yang nantinya perhitungan pada penyakit anjing sesuai dengan fakta gejala yang ada pada tabel kepercayaan. Pengujian sistem dilakukan untuk mengetahui tingkat kesuksesan sistem pakar yang telah dibangun. Pengujian sistem dilakukan melalui dua cara yaitu pengujian blackbox dan pengujian akurasi. Dari percobaan yang telah dilakukan sebanyak 50 data uji didapatkan hasil keluaran sistem yang sesuai sebanyak 45 dimana ketidak sesuaian keluaran dari sistem dengan hasil uji dari pakar terdapat pada data uji nomor 30, 31, 33, 47 dan 50. Sehingga didapatkan nilai akurasi sebesar $90 \%$ dengan kategori baik.

Penelitian selanjutnya dengan objek yang berbeda mengenai aplikasi algoritma naïve bayes untuk mendiagnosa penyakit sapi potong. Algoritma nä̈ve bayes digunakan untuk mengklasifikasi dan menentukan probabilitas yang nantinya perhitungan pada penyakit menular ayam dalam penelitian ini sesuai dengan fakta gejala yang ada pada tabel kepercayaan. Pengujian sistem dilakukan dengan cara yang sama yaitu black box dan pengujian akurasi. Pengujian blackbox menguji fungsionalitas sistem agar dapat berjalan dengan baik. Pengujian akurasi dilakukan dengan membandingkan hasil diagnosis sistem dengan hasil diagnosis seorang pakar. Ratarata akurasi sistem sebesar $93,08 \%$. Tingkat akurasi tertinggi didapat ketika variasi data training berjumlah $40 \%$ dan $60 \%$ dari keseluruhan jumlah data training yang ada. Hal ini membuktikan bahwa komposisi data kasus berpengaruh dalam hasil akurasi sistem. Semakin banyak data training belum tentu dapat menjamin sistem pakar yang dihasilkan akan semakin baik. Jadi dalam menentukkan data training harus berdasarkan komposisi data kasus masing-masing class untuk menghasilkan sistem pakar yang baik [11].

Peneltian berikutnya mengenai sistem pakar diagnosis penyakit sapi dengan metode certainty factor berbasis Android. Certainty Factor digunakan untuk perancangan program aplikasi. Certainty Factor merupakan nilai parameter klinis yang diberikan MYCIN untuk menunjukkan besarnya kepercayaan. Namun dalam penelitian ini hanyalah bersifat prototype [12].

Penelitian dengan objek ayam juga pernah diteliti mengenai sistem pakar diagnosa penyakit saluran pencernaan pada ayam broiler. Sistem dibangun untuk membantu para 
peternak khususnya para pemilik dalam mendapatkan informasi mengenai penyakit saluran pencernaan ayam, sehingga tidak perlu untuk berkonsultasi langsung dengan para pakar (dokter hewan) dan dengan menggunakan metode certainty factor tingkat penyakit saluran pencernaan ayam bisa terditeksi dari gejala-gejala yang ada dan dapat diketahui penyakit tersebut dalam kondisi biasa atau parah [2].

Selanjutnya penelitian perbandingan metode naïve bayes dengan certainty factor pada tanaman melon. Penelitian tersebut membandingkan gejala-gejala penyakit yang dapat menyerang tanaman melon dengan 2 metode. Dari penelitian tersebut dihasilkan aplikasi diagnosis web namun peneliti mengharapkan dapat dibuat ke dalam aplikasi android [13].

\section{METODE PENELITIAN}

Metode penelitian ini menggunakan model prototype untuk pembangunan sistem pakar diagnosa penyakit menular ayam dengan mengimplementasikan nä̈ve bayes - certainty factor. Model prototype digunakan untuk merancang sistem aplikasi melalui 3 tahapan yaitu pengumpulan data pakar, perancangan sistem pakar dan implementasi sebagaimana gambar 1.

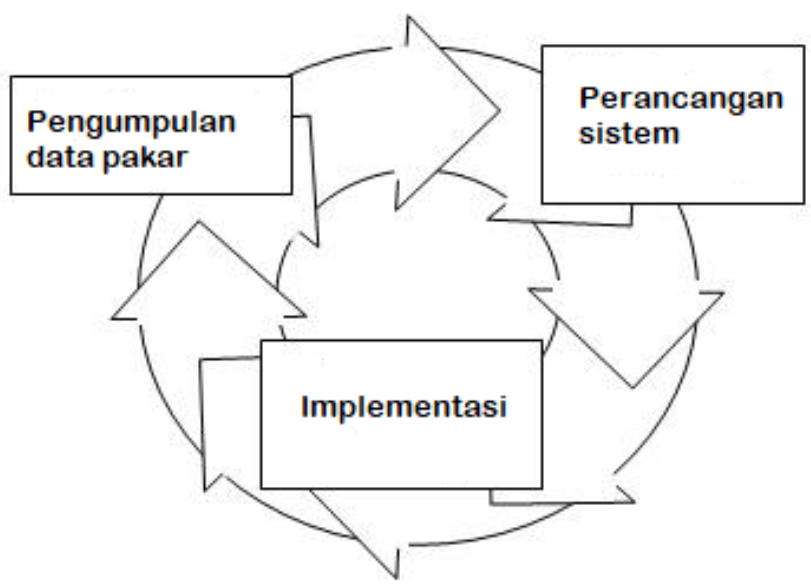

Gambar 1. Model Prototype [14]

Pengumpulan data pakar merupakan tahap analisis kebutuhan dengan mengumpulkan data mengenai bagaimana cara kerja diagnosa penyakit menular hewan peliharaan ayam. Pakar dalam penelitian ini yaitu dokter hewan. Data yang dukumpulkan berasal dari 3 (tiga) orang dokter hewan dengan pengalaman 14 tahun, 5 tahun dan 3 tahun berkerja di klinik hewan. Tahap perancangan sistem, membangun desain sistem dengan menyiapkan desain awal aplikasi berupa mock up antarmuka dan user experience serta perangkat keras dengan spesifikasi sesuai kebutuhan. Pada tahap implementasi dimulai dengan mengimplementasikan hasil rancangan dan basis data, membuat tampilan antarmuka pada android, membuat fungsifungsi front end pada android menggunakan bahasa markup $X M L$ dan bahasa pemrograman Java. Tahap pengujian sistem dilakukan dengan cara menguji fungsi-fungsi sistem yang sudah dibuat secara menyeluruh dengan harapan dapat berfungsi dengan baik.
Teorema Bayes merupakan sebuah pendekatan untuk sebuah ketidaktentuan yang diukur dengan probabilitas [6]. Pada saat klasifikas, pendekatan bayes akan menghasilkan label kategori yang paling tinggi probabilitasnya [15].Adapun tahapan-tahapan dalam metode naive bayes sebagai berikut :

1. Mencari nilai prior untuk tiap-tiap kelas dengan menghitung rata-rata tiap kelas menggunakan persamaan (1).

$$
\mathrm{P}=\mathrm{X} / \mathrm{A}
$$

Keterangan:

$\mathrm{P}=$ Nilai prior

$\mathrm{X}=$ Jumlah data tiap kelas

$\mathrm{A}=$ Jumlah data seluruh kelas

2. Mencari nilai likelihood untuk tiap-tiap kelas dengan persamaan (2).

$$
\mathrm{L}=\mathrm{F} / \mathrm{B}
$$
Keterangan:
$\mathrm{L}=$ Nilai likelihood
$\mathrm{F}=$ Jumlah data fitur tiap kelas
$\mathrm{B}=$ Jumlah seluruh data tiap kelas

3. Mencari nilai posterior pada tiap kelas yang ada menggunakan persamaan (3).

$$
\mathrm{P}(\mathrm{c}) \cdot \prod \mathrm{P}(\mathrm{a} \mid \mathrm{c})
$$

\section{Keterangan: \\ $\mathrm{P}(\mathrm{c})=$ Nilai prior tiap kelas \\ $\mathrm{P}(\mathrm{a} \mid \mathrm{c})=$ Nilai likelihood}

Hasil klasifikasi kelas metode nä̈ve bayes dilakukan dengam membandingkan nilai posterior dari kelas-kelas yang ada. Nilai posterior yang paling tinggi yang terpilih sebagai hasil klasifikasi.

Certainty Factor (CF) merupakan nilai parameter klinis untuk menunjukkan besarnya kepercayaan [16]. Certainty Factor didefinisikan sebagai persamaan (4) :

$$
C F(H, E)=M B(H, E)-M D(H, E)
$$

\section{Keterangan:}

a. CF (H, E): Certainty Factor dari hipotesis $\mathrm{H}$ yang dipengaruhi oleh gejala (evidence) E. Besarnya CF berkisar antara -1 sampai 1 . Nilai -1 menunjukkan ketidak percayaan mutlak sedangkan nilai 1 menunjukkan kepercayaan mutlak.

b. $\mathrm{MB}(\mathrm{H}, \mathrm{E})$ : Ukuran kenaikan kepercayaan (measure of increased belief) terhadap hipotesis $\mathrm{H}$ yang dipengaruhi oleh gejala $\mathrm{E}$.

c. $\mathrm{MD}(\mathrm{H}, \mathrm{E})$ : Ukuran kenaikan ketidak percayaan (measure 
of increased disbelief) terhadap hipotesis $\mathrm{H}$ yang dipengaruhi oleh gejala $\mathrm{E}$.

Bentuk dasar rumus certainty factor, adalah sebuah aturan JIKA E maka H sebagaimana persamaan (5).

$$
\mathrm{CF}(\mathrm{H}, \mathrm{e})=\mathrm{CF}(\mathrm{E}, \mathrm{e}) * \mathrm{CF}(\mathrm{H}, \mathrm{E})
$$

\section{Keterangan:}

a. $\mathrm{CF}(\mathrm{H}, \mathrm{e})$ : Certainty factor hipotesis yang dipengaruhi oleh evidence e.

b. CF (E, e): Certainty factor evidence E yang dipengaruhi oleh evidence e.

c. $\mathrm{CF}(\mathrm{H}, \mathrm{E})$ : Certainty factor hipotesis dengan asumsi evidence diketahui dengan pasti, yaitu ketika $\mathrm{CF}(\mathrm{E}, \mathrm{e})=1$

Jika semua evidence pada antecedent diketahui dengan pasti maka sebagaimana persamaan (6):

$$
\mathrm{CF}(\mathrm{E}, \mathrm{e})=\mathrm{CF}(\mathrm{H}, \mathrm{E})
$$

Pada persamaan 6, $\mathrm{CF}(\mathrm{H}, \mathrm{E})$ merupakan nilai kepastian yang diberikan oleh pakar terhadap suatu aturan, sedangkan $\mathrm{CF}(\mathrm{E}, \mathrm{e})$ merupakan nilai kerpercayaan yang diberikan oleh pengguna terhadap gejala yang dialaminya.

Kebutuhan fungsional sistem dapat dideskripsikan dalam use case diagram untuk menggambarkan aktifitas yang dilakukan oleh pengguna sistem, sebagaimana gambar 2.

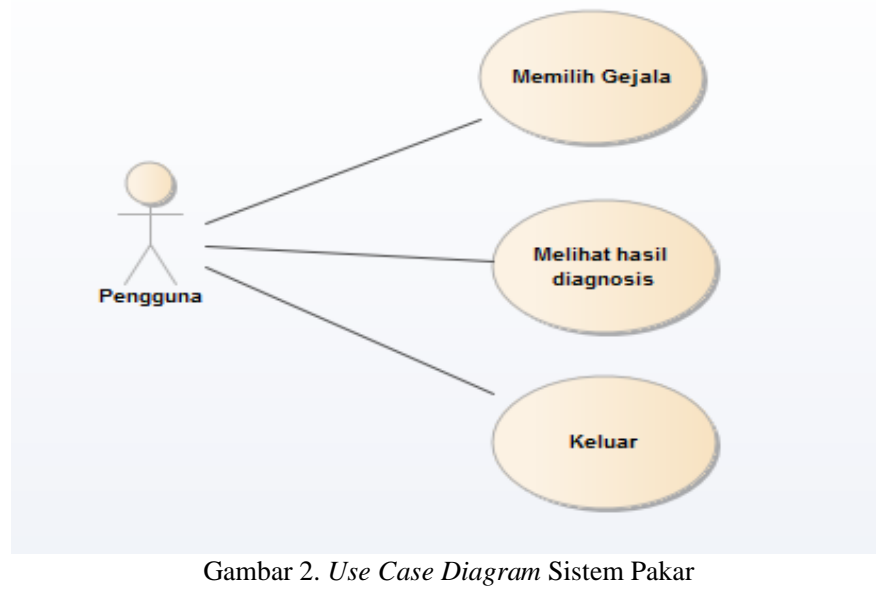

Adapun wujud antar muka aplikasi pada halaman pertama ketika memulai penggunaan aplikasi sebagaimana Gambar 3.

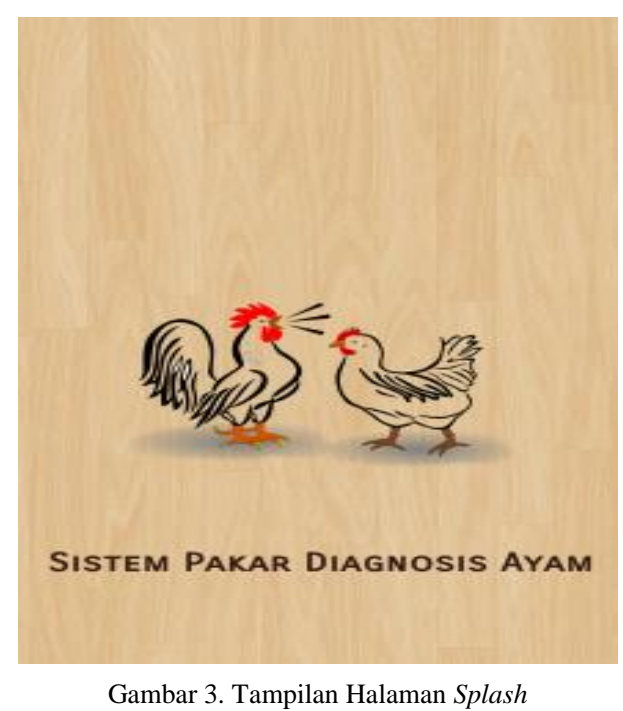

Gambar 3 merupakan halaman splash sebelum menampilkan halaman utama sistem sebagaimana gambar 4.

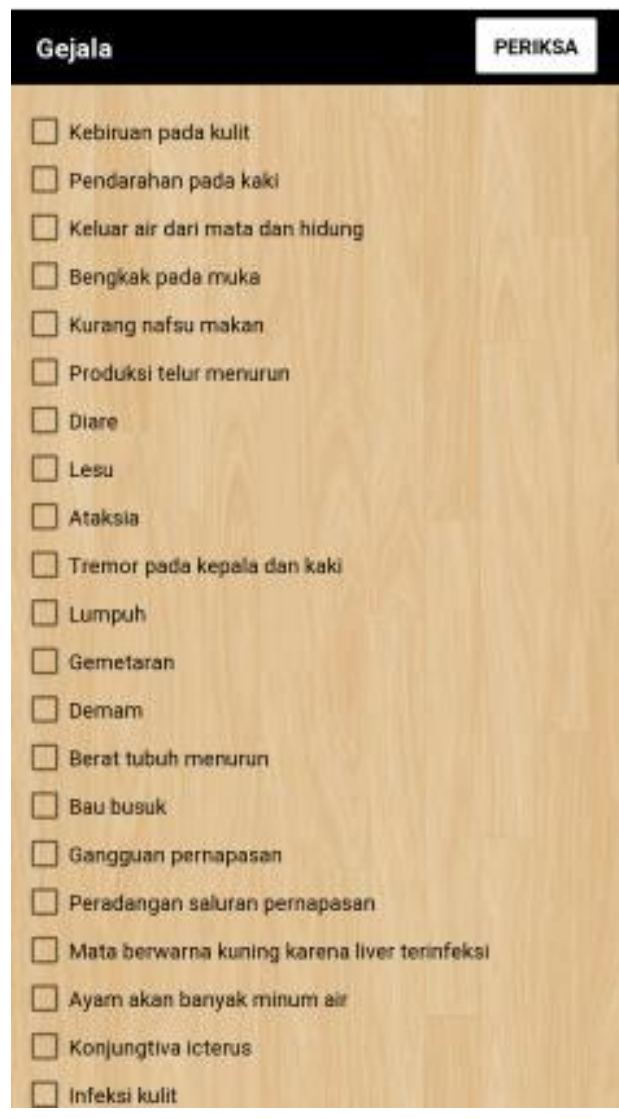

Gambar 4. Tampilan Halaman Utama

Gambar 4 merupakan halaman utama yang menampilkan gejala-gejala penyakit menular hewan peliharaan ayam. Gejala-gejala tersebut dipilih oleh pengguna berdasarkan gejala yang terjadi pada hewan peliharaannya untuk dilakukan diagnosa lebih lanjut. Tampilan halaman hasil diagnosis sebagaimana gambar 5 . 


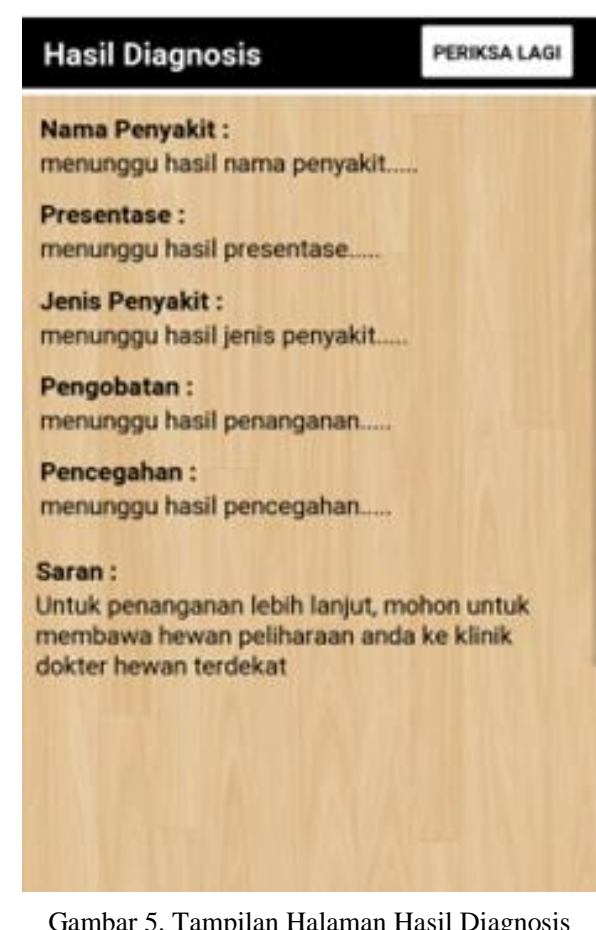

Gambar 5 memperlihatkan hasil proses terhadap gejalagejala yang telah di pilih. Hasil diagnosis meliputi informasi nama penyakit, presentase, jenis penyakit, pengobatan, pencegahan dan saran.

\section{HASIL DAN PEMBAHASAN}

Implementasi metode naïve bayes - certainty factor pada aplikasi diagnosa penyakit menular hewan peliharaan ayam merupakan suatu tahapan penerapan proses perancangan yang telah dibuat sebelumnya. Adapun prosedur sistem sebagaimana Gambar 6 :

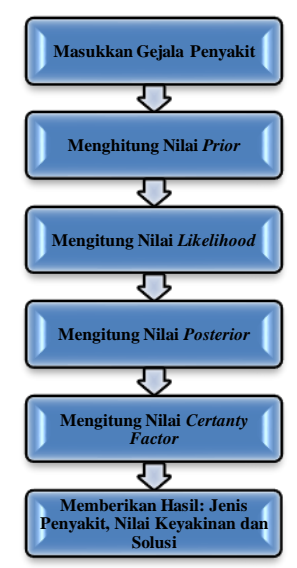

Gambar 6. Prosedur Sistem dengan Metode Nä̈ve Bayes-Certainty Factor

Gambar 6 dapat dijelaskan bahwa terdapat 6 prosedur yang dilakukan sistem mulai dari memasukkan gejala penyakit, menghitung nilai prior, nilai likelihood, nilai posterior dan nilai certainty factor dan terakhir system memberikan hasil berupa jenis penyakit, nilai keyakinan dan solusi yang diberikan. Pohon keputusan diagnosa penyakit menular hewan peliharaan ayam sebagaimana gambar 7 .

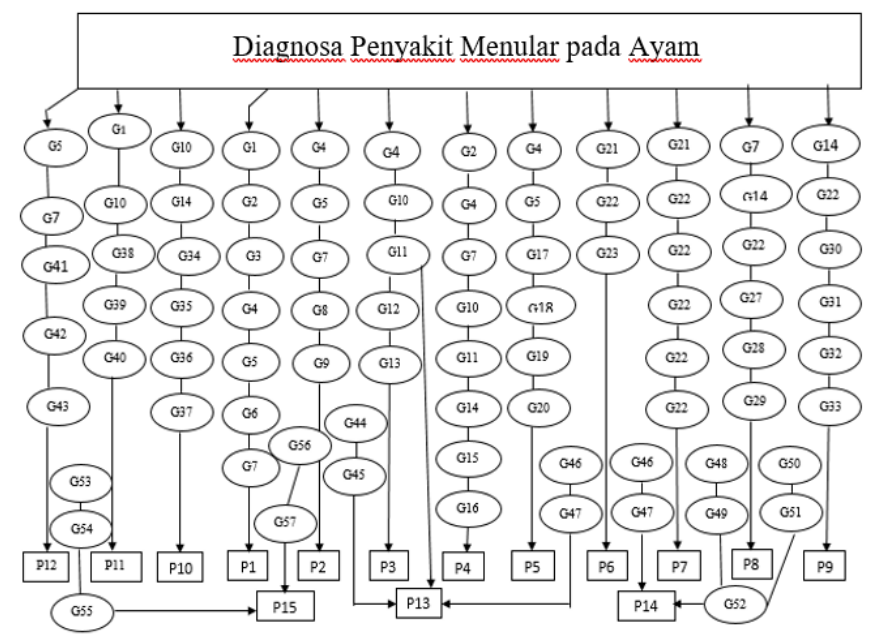

Gambar 7. Pohon Keputusan Diagnosis Penyakit Menular Pada Ayam

Basis pengetahuan yang dibangun untuk sistem diagnosa penyakit menular hewan peliharaan ayam. Sistem ini dapat mengindentifikasi sebanyak 57 gejala dengan jumlah 15 penyakit menular ayam, yaitu Avian influenza, Encephalomyelitis, Chlamydiosis, Pullorum, Fowl Typhoid, Cacar Unggas, Chicken anemia syndrome, Helicopter Disease, Aspergillosis, Infectious Bursal Disease, Infectious Bronchitis, Diare, Bacterial Pododermatitis, Pyotraumatic Dermatitis dan Pyoderma.

Pengujian sistem dilakukan pada halaman utama gambar 4 dengan menggunakan black box testing terhadap proses input dan output sebagaimana table 1.

Tabel 1. Pengujian Black Box Pada Halaman Utama

\begin{tabular}{|c|c|c|c|c|c|}
\hline No & $\begin{array}{c}\text { Skenario } \\
\text { Pengujian }\end{array}$ & $\begin{array}{c}\text { Test } \\
\text { Case }\end{array}$ & $\begin{array}{c}\text { Hasil yang } \\
\text { diharapkan }\end{array}$ & $\begin{array}{c}\text { Hasil } \\
\text { pengujian }\end{array}$ & Kesimpulan \\
\hline 1 & $\begin{array}{c}\text { Mengosongkan } \\
\text { semua } \\
\text { checkbox pada } \\
\text { gejala }\end{array}$ & $\begin{array}{c}\text { Checkbox } \\
1 \text { sampai } \\
57\end{array}$ & $\begin{array}{c}\text { Harus } \\
\text { memilih } \\
\text { salah satu } \\
\text { pertanyaan }\end{array}$ & $\begin{array}{c}\text { Sesuai } \\
\text { harapan }\end{array}$ & Valid \\
\hline 2 & $\begin{array}{c}\text { Memilih } \\
\text { semua check } \\
\text { box pada } \\
\text { semua gejala }\end{array}$ & $\begin{array}{c}\text { Checkbox } \\
1 \text { sampai } \\
\text { semalida }\end{array}$ & $\begin{array}{c}\text { Tidak bisa } \\
\text { memilih } \\
\text { semua } \\
\text { pertanyaan }\end{array}$ & $\begin{array}{c}\text { Sesuai } \\
\text { harapan }\end{array}$ & Valid \\
\end{tabular}

Pengujian pada tabel 1 berfungsi untuk memastikan bahwa suatu event atau masukan akan menjelaskan proses yang tepat dan menghasilkan output yang sesuai. Sebagaimana gambar 6 .

Black box testing pada halaman hasil diagnosis gambar 5 sebagaimana tabel 2 . 
Tabel 2. Pengujian Black Box pada Halaman Hasil Diagnosis

\begin{tabular}{|c|c|c|c|c|c|}
\hline No & $\begin{array}{c}\text { Skenario } \\
\text { Pengujian }\end{array}$ & Test Case & $\begin{array}{l}\text { Hasil yang } \\
\text { diharapkan }\end{array}$ & $\begin{array}{c}\text { Hasil } \\
\text { pengujian }\end{array}$ & $\begin{array}{c}\text { Kesimpu } \\
\text { lan }\end{array}$ \\
\hline 1 & $\begin{array}{c}\text { Hasil } \\
\text { penyakit } \\
\text { virus hanya } \\
\text { ada } \\
\text { pencegahan }\end{array}$ & $\begin{array}{c}\text { jenisPenyakit } \\
\text { = "Penyakit } \\
\text { Virus"; } \\
\text { pencegahanPe } \\
\text { nyakit = "-"; } \\
\text { penangananP } \\
\text { enyakit = } \\
\text { "Vaksinasi"; }\end{array}$ & $\begin{array}{c}\text { Penyakit } \\
\text { virus hanya } \\
\text { ada } \\
\text { pencegahan } \\
\text { saja }\end{array}$ & $\begin{array}{c}\text { Sesuai } \\
\text { harapan }\end{array}$ & Valid \\
\hline 2 & $\begin{array}{c}\text { Hasil } \\
\text { penyakit } \\
\text { parasit } \\
\text { hanya ada } \\
\text { pengobatan }\end{array}$ & $\begin{array}{l}\text { jenisPenyakit } \\
\text { = "Penyakit } \\
\text { Parasit"; } \\
\text { pencegahanPe } \\
\text { nyakit = "-"; } \\
\text { penangananP } \\
\text { enyakit = } \\
\text { "Berikan obat } \\
\text { anti parasit"; }\end{array}$ & $\begin{array}{c}\text { Penyakit } \\
\text { parasit } \\
\text { hanya ada } \\
\text { pengobatan } \\
\text { saja }\end{array}$ & $\begin{array}{c}\text { Sesuai } \\
\text { harapan }\end{array}$ & Valid \\
\hline 3 & $\begin{array}{c}\text { Hasil } \\
\text { penyakit } \\
\text { bakteri ada } \\
\text { pengobatan } \\
\text { dan } \\
\text { pencegahan }\end{array}$ & $\begin{array}{c}\text { jenisPenyakit } \\
=\text { "Penyakit } \\
\text { Bakteri"; } \\
\text { pencegahanPe } \\
\text { nyakit = } \\
\text { "Lingkungan" } \\
\quad ; \\
\text { penangananP } \\
\text { enyakit = } \\
\text { "Antibiotik"; }\end{array}$ & $\begin{array}{c}\text { Penyakit } \\
\text { bakteri ada } \\
\text { pengobatan } \\
\text { dan } \\
\text { pencegahan }\end{array}$ & $\begin{array}{c}\text { Sesuai } \\
\text { harapan }\end{array}$ & Valid \\
\hline 4 & Saran & $\begin{array}{c}\text { android:text= } \\
\text { "Untuk } \\
\text { penanganan } \\
\text { lebih lanjut, } \\
\text { mohon untuk } \\
\text { membawa } \\
\text { hewan } \\
\text { peliharaan } \\
\text { anda ke klinik } \\
\text { dokter hewan } \\
\text { terdekat" }\end{array}$ & $\begin{array}{c}\text { Menampilk } \\
\text { an saran } \\
\text { pada } \\
\text { halaman } \\
\text { hasil }\end{array}$ & $\begin{array}{c}\text { Sesuai } \\
\text { harapan }\end{array}$ & Valid \\
\hline
\end{tabular}

Pengujian akurasi sistem dilakukan untuk mengetahui performa dari sistem pakar yang telah dibangun dan berapa besar tingkat akurasi dalam memberikan hasil diagnosis penyakit menular pada hewan peliharaan ayam berdasarkan masukan gejala-gejala yang dipilih oleh pengguna. Total data uji yang digunakan sebanyak 50 data untuk membandingkan hasil uji sistem dengan hasil uji pakar. Sebagaimana table 3.

Tabel 3. Hail Pengujian Akurasi

\begin{tabular}{|c|c|c|c|}
\hline No & Diagnosis Pakar & Diagnosis Sistem & $\begin{array}{c}\text { Nilai CF } \\
(\mathbf{\%})\end{array}$ \\
\hline 1 & Avian influenza & Avian influenza & $95.20 \%$ \\
\hline 2 & Encephalomyelitis & Encephalomyelitis & $99.83 \%$ \\
\hline 3 & Chlamydiosis & Chlamydiosis & $99.80 \%$ \\
\hline 4 & Pullorum & Pullorum & $98 \%$ \\
\hline 5 & Fowl Typhoid & Fowl Typhoid & $84 \%$ \\
\hline 6 & Cacar Unggas & Cacar Unggas & $90.40 \%$ \\
\hline 7 & Chicken anemia & Chicken anemia syndrome & \\
& syndrome & Null & $98 \%$ \\
\hline 8 & Avian influenza & Helicopter Disease & $97.60 \%$ \\
\hline 9 & Helicopter Disease & Aspergillosis & $76 \%$ \\
\hline 10 & Aspergillosis & Diare & $98.40 \%$ \\
\hline 11 & Infectious Bursal Disease & Infectious Bursal Disease & $96.00 \%$ \\
\hline 12 & Infectious Bronchitis & Bacterial Pododermatitis & $60.00 \%$ \\
\hline 13 & Bacterial Pododermatitis & .
\end{tabular}

\begin{tabular}{|c|c|c|c|}
\hline No & Diagnosis Pakar & Diagnosis Sistem & $\begin{array}{c}\text { Nilai CF } \\
(\%)\end{array}$ \\
\hline 14 & Pyotraumatic Dermatitis & Pyotraumatic Dermatitis & $76.00 \%$ \\
\hline 15 & Bacterial Pododermatitis & Bacterial Pododermatitis & $99.20 \%$ \\
\hline 16 & Pyotraumatic Dermatitis & Pyotraumatic Dermatitis & $99.20 \%$ \\
\hline 17 & Fowl Typhoid & Avian influenza & $80.00 \%$ \\
\hline 18 & Avian influenza & Fowl Typhoid & $95.20 \%$ \\
\hline 19 & Encephalomyelitis & Encephalomyelitis & $94.00 \%$ \\
\hline 20 & Chlamydiosis & Chlamydiosis & $98.00 \%$ \\
\hline 21 & Pullorum & Pullorum & $96.00 \%$ \\
\hline 22 & Fowl Typhoid & Fowl Typhoid & $98.00 \%$ \\
\hline 23 & Cacar Unggas & Cacar Unggas & $88.00 \%$ \\
\hline 24 & $\begin{array}{c}\text { Chicken anemia } \\
\text { syndrome }\end{array}$ & Chicken anemia syndrome & $98.00 \%$ \\
\hline 25 & Avian influenza & Avian influenza & $97.60 \%$ \\
\hline 26 & Helicopter Disease & Helicopter Disease & $98.00 \%$ \\
\hline 27 & Aspergillosis & Aspergillosis & $90.00 \%$ \\
\hline 28 & Infectious Bursal Disease & Infectious Bursal Disease & $92.00 \%$ \\
\hline 29 & Infectious Bronchitis & Infectious Bronchitis & $52.00 \%$ \\
\hline 30 & Pyotraumatic Dermatitis & Pyotraumatic Dermatitis & $88.00 \%$ \\
\hline 31 & Cacar Unggas & Cacar Unggas & $99.60 \%$ \\
\hline 32 & $\begin{array}{c}\text { Chicken anemia } \\
\text { syndrome }\end{array}$ & Chicken anemia syndrome & $97.60 \%$ \\
\hline 33 & Avian influenza & Avian influenza & $94.00 \%$ \\
\hline 34 & Helicopter Disease & Helicopter Disease & $98 \%$ \\
\hline 35 & Parvovirus & Parvovirus & $98.00 \%$ \\
\hline 36 & Fowl Typhoid & Fowl Typhoid & $99.60 \%$ \\
\hline 37 & Pullorum & Pullorum & $99.00 \%$ \\
\hline 38 & Infectious Bursal Disease & Infectious Bursal Disease & $99.36 \%$ \\
\hline 39 & Infectious Bronchitis & $\overline{\text { NULL }}$ & $0.00 \%$ \\
\hline 40 & Bacterial Pododermatitis & Bacterial Pododermatitis & $68.00 \%$ \\
\hline 41 & Pyotraumatic Dermatitis & Pyotraumatic Dermatitis & $99.68 \%$ \\
\hline 42 & Bacterial Pododermatitis & Bacterial Pododermatitis & $99.40 \%$ \\
\hline 43 & Pyotraumatic Dermatitis & Pyotraumatic Dermatitis & $98.40 \%$ \\
\hline 44 & Infectious Bursal Disease & Infectious Bursal Disease & $92.00 \%$ \\
\hline 45 & Avian influenza & Avian influenza & $40.00 \%$ \\
\hline 46 & Encephalomyelitis & Encephalomyelitis & $99.92 \%$ \\
\hline 47 & Chlamydiosis & Chlamydiosis & $98.00 \%$ \\
\hline 48 & Pullorum & Pullorum & $96.40 \%$ \\
\hline 49 & Fowl Typhoid & Fowl Typhoid & $20.00 \%$ \\
\hline 50 & Avian influenza & Avian influenza & $98.00 \%$ \\
\hline
\end{tabular}

Berdasarkan tabek 3, terdapat 45 data yang memiliki hasil diagnosis yang sama dengan hasil uji pakar, sehingga tingkat akurasi pengujian sebagaimana berikut:

\section{Akurasi \%=(Jumlah Data Uji Benar) $/(J u m l a h$ Total Data} Uji) $\times 100 \%$

$$
\text { Akurasi } \%=45 / 50 \times 100 \%=90 \%
$$

Tingkat akurasi yang dihasilkan oleh sistem pakar diagnosis penyakit menular pada ayam menggunakan metode naïve bayes- certainty factor adalah sebesar $90 \%$. Diagram pengujian akurasi sistem sebagaimana Gambar 7.

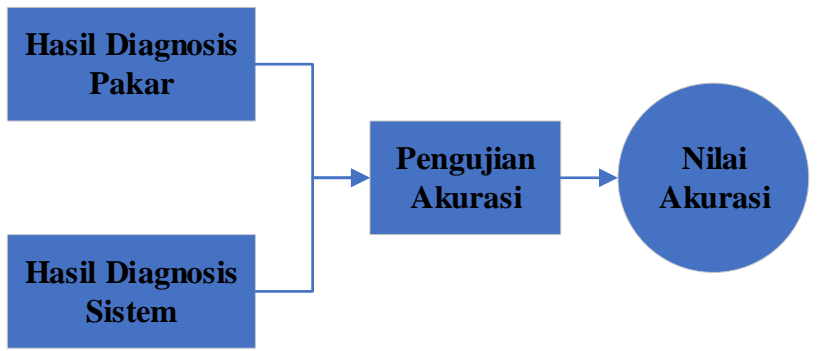

Gambar 7. Diagram Pengujian Akurasi Sistem 
Berikut table hasil pengujian akurasi, sebagaimana table 3.

\section{KESIMPULAN}

Aplikasi sistem pakar diagnosa penyakit menular hewan peliharaan ayam menggunakan metode naïve bayes - certainty factor dengan 50 data uji, berdasarkan table 3 hasil pengujian akurasi terlihat bahwa terdapat 45 data uji sesuai dengan diagnosis pakar. 5 data uji yang 2 diantaranya tidak menghasilkan diagnosis sistem yaitu Avian influenza dan Infectious bronchitis. 3 diantaranya tidak sesuai dengan diagnosis pakar. Sehingga tingkat akurasi yang dihasilkan sebesar $90 \%$, dapat dikatakan bahwa ketepatan hasil diagnosis dalam kategori baik.

\section{REFERENCES}

[1] A. G. Nataamijaya, "Pengembangan Potensi Ayam Lokal Untuk Menunjang Peningkatan Kesejahteraan Petani," vol. 29, no. 4, pp. 131138, 2010, doi: 10.21082/jp3.v29n4.2010.p131-138.

[2] J. Rahmah and R. A. Saputra, "Penerapan Certainty Factor Pada Sistem Pakar Diagnosa Penyakit Saluran Pencernaan Ayam Broiler," J. Inform., vol. 4, no. 1, pp. 94-102, 2017.

[3] E. Wiedosari and S. Wahyuwardani, "Studi Kasus Penyakit Ayam Pedaging Di Kabupaten Sukabumi Dan Bogor," J. Kedokt. Hewan Indones. J. Vet. Sci., vol. 9, no. 1, pp. 9-13, 2015, doi: 10.21157/j.ked.hewan.v9i1.2777.

[4] A. Himawan, N. Hidayat, and M. T. Ananta, "Sistem Diagnosis Penyakit Hewan Pada Anjing Dengan Menggunakan Metode Naive Bayes," J. Pengemb. Teknol. Inf. dan Ilmu Komput. Univ. Brawijaya, vol. 2, no. 10, pp. 4290-4295, 2018.

[5] I. Candra Dewi, A. Andy Soebroto, and M. Tanzil Furqon, "Sistem Pakar Diagnosa Penyakit Sapi Potong Dengan Metode Naive Bayes," J. Enviromental Eng. Sustain. Technol., vol. 2, no. 2, pp. 72-78, 2015, doi: 10.21776/ub.jeest.2015.002.02.2.
[6] A. Syahrawardi, N. Hidayat, and D. Sihombing, "Sistem Pakar Diagnosis Hama-Penyakit Pada Tanaman Sedap Malam Menggunakan Metode Naïve Bayes-Certainty Factor Berbasis Android," Pengemb. Teknol. Inf. dan Ilmu Komput., vol. 2, no. 1, pp. 153-160, 2018.

[7] A. H. Pratama, "Aplikasi Sistem Pakar Untuk Identifikasi Hama Dan Penyakit Tanaman Tebu Dengan Metode Naive Bayes Berbasis Web," Universitas Brawijaya, 2014.

[8] I. Fauz Rohman, P. Harsani, and A. Qur, "Aplikasi Diagnosis Penyakit Sapi Menggunakan Metode Certainty Factors Berbasis Android," 84 $\square \square$ Komputasi, vol. 13, no. 2, pp. 84-93, 2016.

[9] I. H. Santi and B. Andari, "Sistem Pakar Untuk Mengidentifikasi Penyakit Mata Dengan Metode Certainty Factor," INTENSIF, vol. 3, no. 2, pp. 159-177, 2019, doi: 10.33322/kilat.v8i1.367.

[10] T. Sutojo et al., Kecerdasan Buatan. Yogyakarta: Andi Offset, 2011.

[11] I. C. Dewi, A. A. Soebroto, M. T. Furqon, and U. Brawijaya, "SISTEM PAKAR DIAGNOSA PENYAKIT SAPI POTONG DENGAN METODE," vol. 02, no. 02, pp. 67-73, 2015.

[12] S. Sibagariang, "Sistem Pakar Diagnosa Penyakit Sapi Dengan Metode Certainty Factor Berbasis Android," J. TIMES, vol. 3, no. 2, pp. 35-39, 2008.

[13] Kessowosidi, "Perbandingan Naive Bayes dan certanty Factor dalam Diagnosa Hama pada Tanaman Melon," Surakarta, 2017.

[14] D. Purnomo, "Model Prototyping Pada Pengembangan Sistem Informasi," J I M P - J. Inform. Merdeka Pasuruan, vol. 2, no. 2, pp. 54-61, 2017, doi: 10.37438/jimp.v2i2.67.

[15] F. Ahmad, "Perbandingan metode naive-bayes dengan metode certainty factor dalam diagnosa penyakit pada kucing peliharaan," Universitas Pendidikan Indonesia, 2017.

[16] D. Tungga Satya and N. Hidayat, "Sistem Pakar Diagnosis Penyakit Sapi Ternak Potong Menggunakan Metode Naïve Bayes-Certainty Factor," vol. 2, no. 10, pp. 3406-3410, 2018. 